\title{
Megoldást jelent-e a szögstabil implantátumok bevezetése a proximalis humerus törések ellátásában?
}

\author{
DR. CSONKA ÁKOS, DR. GÁRGYÁN ISTVÁN, DR. BÖRÖNDY JÁNOS, \\ DR. BOA KRISTÓF, DR. VARGA ENDRE
}

\section{ÖSSZEFOGLALÁS}

A váll az ember egyik legfontosabb ízülete. Lehetővé teszi a felső végtag aktív munkavégzését, a kéz igény szerinti mozgatását, amivel aztán a finommozgásokat végzi. A vállmozgásokat beszűkítő kórképek nem csak az adott ízület funkciójának gyengülését jelentik, hanem az érintett felső végtag jelentős mozgáskorlátozottságát is okozzák. Egy használhatatlan kar lehetetlenné teheti az alapvető napi rutin és a személyes higiéné ellátását is. Az életkor előrehaladtával a vállizületet érintő balesetek egyre gyakoribbá válnak. A vállat érő traumás károsodások közül a humerus proximalis vég törése a leggyakoribb töréstípus, különösen az osteoporotikus idős korosztály körében. A sérülés jelentősége, hogy megfelelő kezelés ellenére is tartós fájdalmakat okozhat az érintett váll és kar területén, és a mozgástartomány beszűkülése erősen korlátozhatja az önellátást. Az egyén számára életminőség romlást, a környezet számára jelentős szociális megterhelést jelent. Az elmúlt években egyre népszerúbbé vált a szögstabil implantátumok alkalmazása a törések ellátása során. Vizsgálataink során arra kerestük a választ, hogy ezek az implantátumok megoldást jelenthetnek-e a proximalis humerus törések kezelésében.

\section{Kulcsszavak: $\quad$ Humerus törés; Osteoporosis; Szögstabil implantátum; Töréskezelés; Belsö rögzítés; Válltörés;}

Á. Csonka, I. Gárgyán, J. Böröndy, K. Boa, Z. Varga: Are angular stable implants suitable for the treatment of proximal humeral fractures?

The shoulder is one of the most important joints of the human body. It permits activities of the upper extremity, as well as providing voluntary and fine motor movements of the hand. Conditions causing limited range of motion of the shoulder do not only impair shoulder function, but they result in marked disability of the upper extremity. An unusable arm may prevent performing daily activities and activities concerning personal hygiene. Accidents affecting the shoulder become more prevalent with age. Proximal humeral fracture is the most common traumatic fracture type of the shoulder, especially amongst the elderly with osteoporosis. This condition is very important, as it can result in chronic shoulder and arm pain despite proper management, and limited range of motion can interfere with self-sufficiency. It can result in impaired quality of life and it can be a significant burden for the patient's social circle. Angular stable implants have become more-and-more popular in fracture management during the past few years. Our aim was to investigate whether these implants can provide a solution in the management of proximal humeral fractures.

Keywords: $\quad$ Bone plates; Fracture fixation, Internal-Methods;

Humeral fractures - Surgery; Osteoporotic Fractures - Surgery;

Shoulder fractures - Surgery; 


\section{BEVEZETÉS}

A proximalis humerus törések gyakori sérülések, amelyek az összes felnőttkori törés 5-6\%-át teszik ki $(3,4)$. Főleg idős nőbetegek esetében fordulnak elő. Gyakoriságuk a lakosság elöregedésével jelentősen emelkedik. A törések csaknem $85 \%$-a nem vagy minimálisan diszlokált és konzervatív kezeléssel jó eredmény érhető el (10). A diagnózis felállításához konvencionális AP irányú, axialis és scapula $Y$ röntgenfelvételek készítése nyújt segítséget. Amennyiben a röntgenfelvételek nem adnak biztosan megítélhető képet, akkor CT vizsgálat szükséges, esetleg 3D kiegészítéssel (7). A törések osztályozásához leggyakrabban az AO, illetve Neer-féle beosztást alkalmazzuk. A prognózis a 11 AO A1-től a 11 AO C3-ig haladva fokozatosan romlik. A Neer-féle skálán ugyanez tapasztalható; egy törtrész minimális elmozdulással jó prognózist jelent, a nagy elmozdulással járó négyrész törések pedig rossz prognózist mutatnak (12). A medialis humerus metaphysis törtdarab nagysága, valamint az elmozdulás mértéke segít megítélni a várható ischaemia mértékét, illetve az avascularis fejnecrosis létrejöttének az esélyét. A stabilitás szempontjából fontos a törtdarab nagysága, valamint a Hill-Sachs vagy reverz Hill-Sachs, más néven McLaughlin laesio megléte, ami a humerusfej anteromedialis részének törése (11).

A terápiás spektrum a konzervatívan jól kezelhető 11 AO A1 minimálisan diszlokált töréstől terjed a fejmegtartó tűződrótok, csavarok, hagyományos $T$ lemezen át a szögstabil velőürszegek (B.Braun $\operatorname{Targon}^{\circledR}$, Synthes Multiloc $^{\top \mathrm{M}}$ ), illetve szögstabil lemezekig, a vállízületi protézissel bezárólag $(8,9)$. A kezelés eredményét befolyásolhatják a sérült kísérőbetegségei, életmódja, illetve együttmúködési készsége. A diszlokált proximalis humerus törések kezelésében jelenleg nincs tudományos megalapozottságú "gold standard". Ezt a számos mútéti módszer is bizonyítja (1). Súlyos osteoporosis, nagyfokú dislocatio esetén protetizálás javasolt. Amennyiben azonban a törés jellege alapján megfelelő indikáció áll fenn, törekedni kell fejmegtartó mútét elvégzésére, melynek során a törés rögzítését szögstabil implantátumokkal javasolt elvégezni (2).

\section{ANYAG ÉS MÓDSZER}

Retrospektív vizsgálatot folytattunk a klinikánkon ellátott 11 AO A1-C3 típusú proximalis humerusvég törések mútéti kezeléséről és az észlelt szövődményekről. 2008. január 1. és 2014. január 1. között 1888 proximalis humerus törött beteget láttunk el. Ebből 180 esetben (11\%) végeztünk mútétet (1. ábra). A mútét tervezéséhez a röntgenfelvételek mellett szükség esetén $\mathrm{CT}$, illetve $3 \mathrm{D} / \mathrm{CT}$ rekonstrukciót végeztünk. Intézetünkben a végleges mútéti ellátásra a lágyrészek állapotának rendeződése után (a sérüléstől számított 5 napon belül) került sor, ami a szakirodalom szerint elfogadott és nem növeli a későbbi szövődmények számát. Természetesen a fejkalottát érintő törések, illetve a nagy dislocatióval járó törések esetén törekedtünk a mielőbbi mútéti ellátásra, hogy csökkentsük az avascularis necrosis kialakulásának lehetőségét. A posztoperatív röntgenfelvételeken elemeztük a repozíció eredményességét, majd a 6., 12., 16., 26. és 52 . héten készült röntgenfelvételeken tanulmányoztuk az esetleges redislocatiót, avascularis fejnecrosist, valamint a törésgyógyulás mértékét. Vizsgáltuk a sérült vállízület mozgástartományát. Az eredményeket a Constant Score alapján értékeltük. 


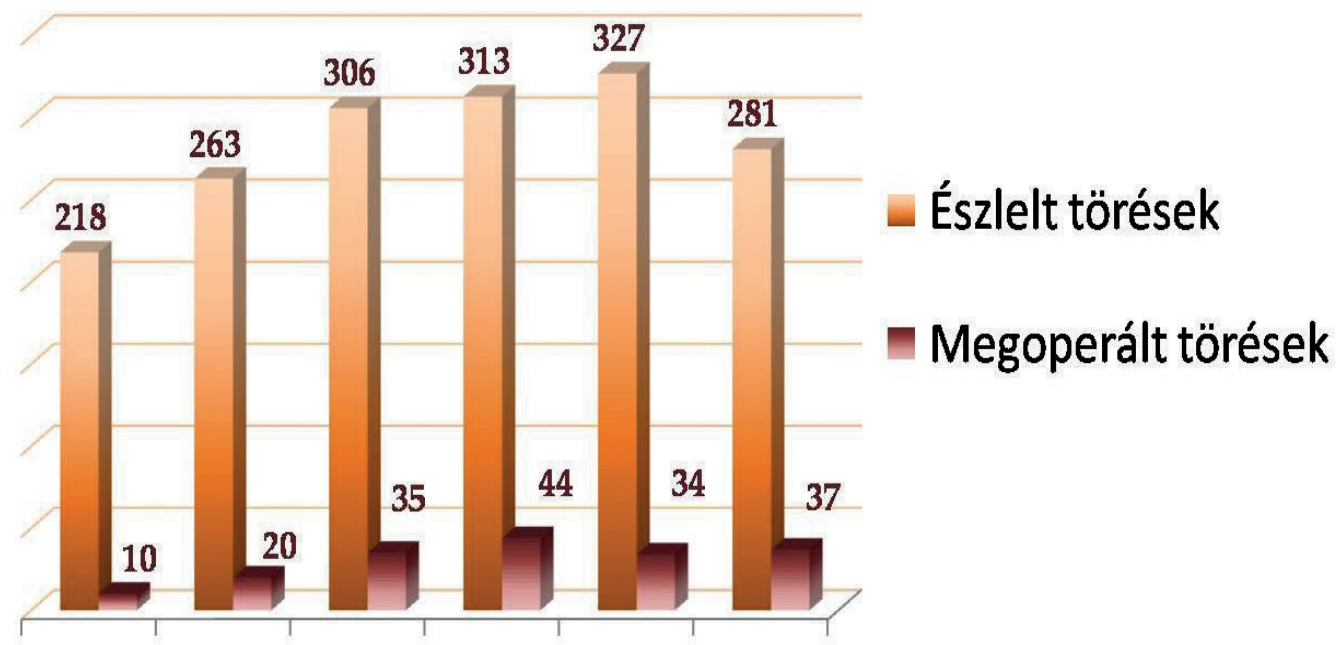

\section{3}

1. ábra Klinikánkon észlelt és megoperált betegek számának alakulása.

\section{MEGFIGYELÉSEK}

A vizsgált időszakban 180 proximalis humerus törött beteget kezeltünk mütéttel. A megoperált betegek száma az idő előrehaladtával négyszeresére nőtt. Hagyományos implantátumot 40 esetben (22\%), míg szögstabil implantátumot 140 esetben (78\%) alkalmaztunk (2. ábra). A betegek életkor szerinti megoszlására jellemző volt, hogy túlnyomó többségük az 50 és 90 év közötti populációba tartozott. A Constant Score megoszlását a 3. ábra szemlélteti a különböző mútéttípusok esetén. Néhány mútéti típus (tűződrót, csavar, hagyományos T-lemez) statisztikailag nem volt értékelhető a kis esetszám miatt. A többi mútéti megoldás esetében az alacsony értékek okai voltak: nem tökéletes repozíció, túlérő csavar vagy velőürszeg, impingementet okozó magas helyzetű lemez, késői fejnekrózis. A Constant Score értékek alakulását Targon és PHILOS lemez alkalmazásánál a 4. ábra szemlélteti.

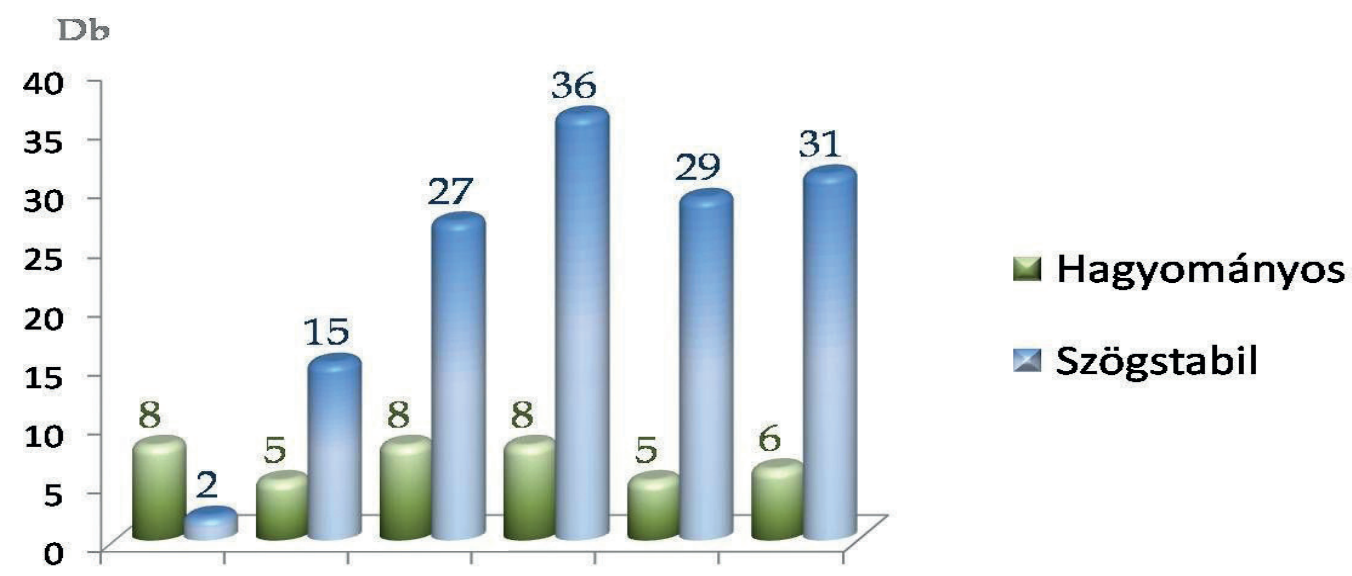

200820092010201120122013

2. ábra A hagyományos és a szögstabil implantátumok egymáshoz viszonyított aránya. 


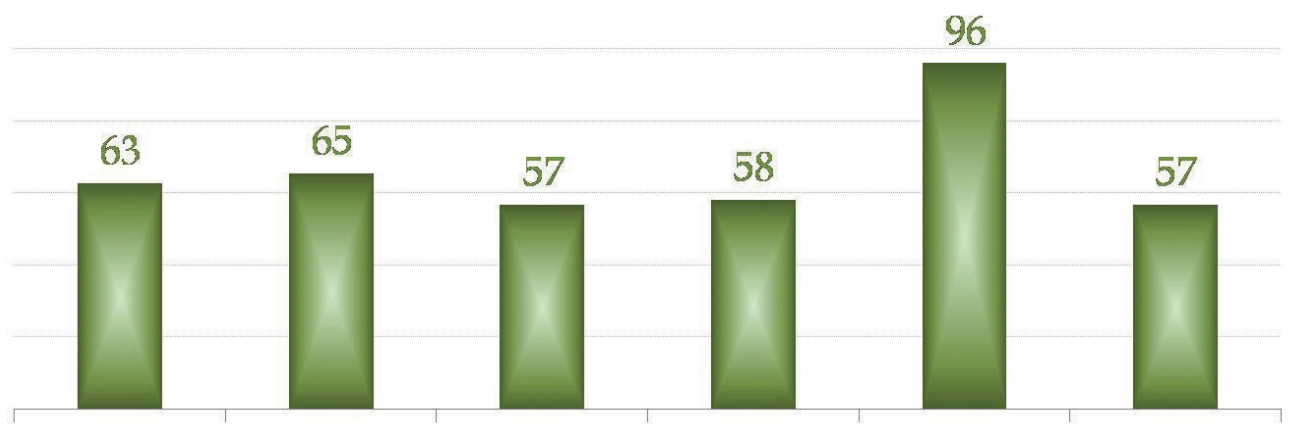

\section{Targon Multilock PHILOS Túzódrót Csavar T-lemez}

3. ábra Constant Score alakulása a különböző implantátum típusok esetén. A hagyományos csavaros osteosynthesissel ellátott betegek kimagasló pontértékét a törések egyszerű volta és a kis esetszám magyarázza.

\section{PHILOS}

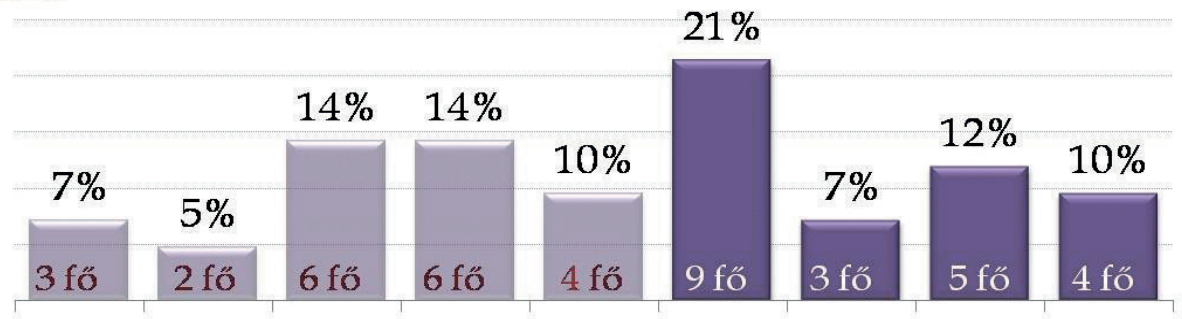

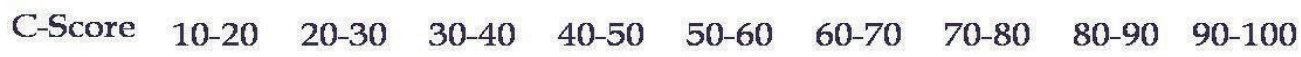

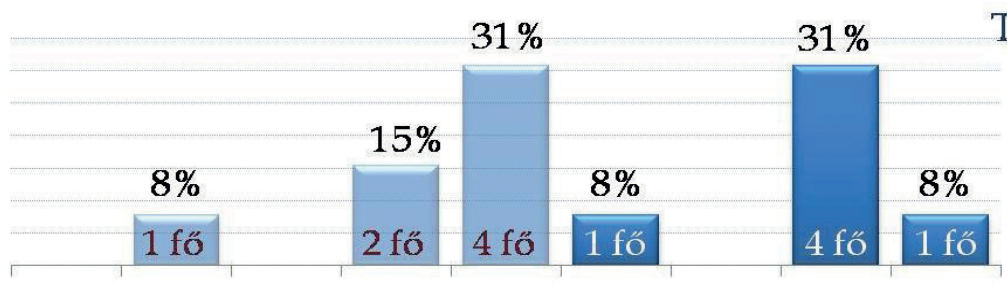

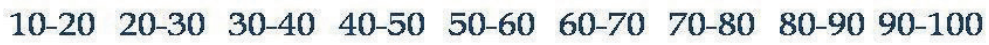

C-Score

4. ábra Constant Score PHILOS és Targon szeg alkalmazása esetén. 


\section{MEGBESZÉLÉS}

A proximalis humerus törések fóként az idős korosztály osteoporosis talaján keletkezett sérülései. Előfordulásuk nők esetében gyakoribb és legtöbbször minor trauma következménye (5). Jelentőségüket az egyre nagyobb számú előfordulásuk és a kezelési nehézségek adják. A terápia megválasztásánál több szempontot kell figyelembe venni, mint például a csont minőségét, a humerusfej vérellátását, a rotátor köpeny állapotát, a sérült általános állapotát és társbetegségeit, a rendelkezésre álló implantátumokat és a traumatológus jártasságát ezek alkalmazásában. A stabil, kis elmozdulással járó törések jól kezelhetőek konzervativ módon, megfelelő funkcionális végeredményt biztosítva a beteg számára (6). A patológiás, a nagy elmozdulással járó, fejkalottát érintő törések esetében ajánlott a mútéti ellátás, míg a nyílt, vagy ér és idegsérüléssel járó törések esetén abszolút mútéti indikáció áll fenn. A folyamatosan növekvő rekonstrukciós lehetőségek nehéz döntés elé állítják a baleseti sebészeket. A kezelési stratégia megválasztása minden esetben személyre szabottan kell, hogy történjen, a sérülttel egyeztetve (14). Az intézetünkben észlelt proximalis humerusvég törötteknél a korábbi években elsősorban a funkcionális kezelést alkalmaztuk. Az utóbbi időben a kezelési stratégiánk egyre inkább eltolódik a mútéti ellátás irányába. Klinikánkon elfogadott módszerként a szögstabil implantátumokat alkalmazzuk. Fiatal, jó csontállományú betegek esetében a $11 \mathrm{AO}$ $A 2, A 3, B 1$ típusú töréseket lehetőség szerint velőúrszeggel, míg a 11 AO B2, B3 illetve C1-3 típusúakat szögstabil lemezzel stabilizáljuk. Idős betegeknél, az osteoporotikus csontállomány és a nagy diszlokációval járó törések esetén (11 AO A3, B3, C3) lehetőség szerint a protézis beültetést helyezzük előtérbe. A nemzetközi szakirodalom is ezt a tendenciát támasztja alá. Például, a Tübingeni Egyetem Traumatológiai Klinikáján a proximalis humerusvég töröttek 80\%-át kezelték operatív módszerrel, míg az alapellátó kórházakban csak a sérültek $20 \%$-át. $\mathrm{Az}$ általuk behelyezésre került implantátumok közel 90\%-a szögstabil rendszer volt. A protézis beültetés aránya a nagy diszlokációval járó 11 AO A3, B3, C3-as típusú töréseknél elérte a 40\%-ot (13). Utánvizsgálatunk alapján megállapítható, hogy a szögstabil implantátumok alkalmazása osteoporotikus csontokon kevesebb redislocatióval, implantátum kilazulással jár, mint a hagyományos lemezek vagy csavarok esetében, azonban az avascularis necrosis kialakulására nincs befolyása. Az avascularis necrosis kialakulása és a mútét időpontja között azonban szoros az összefüggés. Az alacsony Constant Score értékek esetében a nem tökéletes törés repozíció, a nem megfelelő helyzetú implantátum, túlérő csavar vagy velőűrszeg, illetve a késői fejnecrosis játszott szerepet. Az új szögstabil implantátumok bővítették az operativ lehetőségeinket, azonban nem oldják meg a humerusfej keringési zavarait. A mútéttechnikai hibák pedig rontják a végeredményt. Eredményeink alapján megállapíthatjuk, hogy az új és korszerű szögstabil implantátumok következetes és gondos mútéttechnika alkalmazása mellett egyszerúbbé és jobbá teszik ezeknek a sérüléseknek az ellátását. 


\section{IRODALOM}

1. Aaron D., Shatsky J., Paredes J. C., Jiang C., Parsons B. O., Flatow E. L.: Proximal humeral fractures: internal fixation. Instr. Course Lect. 2013. 62: 143-154.

2. Bahrs C., Kühle L., Blumenstock G., Stöckle U., Rolauffs B., Freude T.: Which parameters affect medium- to long-term results after angular stable plate fixation for proximal humeral fractures? J. Shoulder Elbow Surg. 2015. 24. (5): 727-732. https://doi.orq/10.1016/i.jse.2014.08.009

3. Baron J. A., Barrett J. A., Karagas M. R.: The epidemiology of peripheral fractures. Bone. 1996. 18. (3): $209-213$. https://doi.orq/10.1016/8756-3282(95)00504-8

4. Bengnér U., Johnell O., Redlund-Johnell I.: Changes in the incidence of fracture of the upper end of the humerus during a 30-year period. A study of 2125 fractures. Clin. Orthop. Relat. Res. 1988. (231): 179-182.

5. Court-Brown C. M., Garg A., McQueen M. M.: The epidemiology of proximal humeral fractures. Acta Orthop. Scand. 2001. 72 : 365-371. https://doi.orq/10.1080/000164701753542023

6. Lefevre-Colau M. M., Babinet A., Fayad F., Fermanian J., Anract P., Roren A., Kansao J., Revel M., Poiraudeau S.: Immediate mobilization compared with conventional immobilization for the impacted nonoperatively treated proximal humeral fracture. A randomized controlled trial. J. Bone Joint Surg. Am. 2007. 89: 2582-2590. https://doi.orq/10.2106/JBJS.F.01419

7. Lill H., Ellwein A., Katthagen C., Voigt C.: Osteoporotische Frakturen am proximalen Humerus. Chirurg. 2012. 83. (10): 858-865. https://doi.org/10.1007/s00104-012-2337-3

8. Maier D., Jaeger M., Izadpanah K., Strohm P. C., Suedkamp N. P.: Proximal humeral fracture treatment in adults. J. Bone Joint Surg. Am. 2014. 96. (3): 251-261. https://doi.org/10.2106/JBJS.L.01293

9. Neviaser R. J., Resch H., Neviaser A. S., Crosby L. A.: Proximal humeral fractures: pin, plate, or replace. Instr. Course Lect. 2015. 64: 203-214.

10. Roux A., Decroocq L., El Batti S., Bonnevialle N., Moineau G., Trojani C., Boileau P., de Peretti F.: Epidemiology of proximal humerus fractures managed in a trauma center. Orthop. Traumatol. Surg. Res. 2012. 98. (6): 715-719. https://doi.org/10.1016/j.otsr.2012.05.013

11. Sandstrom C. K., Kennedy S. A., Gross J. A.: Acute shoulder trauma: what the surgeon wants to know. Radiographics. 2015. 35. (2): 475-492. https://doi.org/10.1148/rg.352140113

12. Siebenrock K. A., Gerber C.: Frakturklassifikation und Problematik bei proximalen Humerusfrakturen. Orthopäde. 1992. 21. (2): 98-105.

13. Tepass A., Weise K., Rolauffs B., Blumenstock G., Bahrs C.: Behandlung proximaler Humerusfrakturen in Deutschland: Einfluss von Krankenhausversorgungsstufe und Behandlungsfrequenz. Unfallchirurg. 2015. 118. (9): $772-779$. https://doi.ora/10.1007/s00113-013-2531-x

14. Vachtsevanos L., Hayden L., Desai A. S., Dramis A.: Management of proximal humerus fractures in adults. World J. Orthop. 2014.5. (5): 685-693. https://doi.ora/10.5312/wio.v5.i5.685

\section{Dr. Csonka Ákos}

SZTE Szent-Györgyi Albert Klinikai Központ, Traumatológiai Klinika

6725 Szeged, Semmelweis u. 6. 